\title{
TERUGBLIK AIDSTIJDPERK 1981-1996
}

door

HUGO SCHALKWIJK

adviseur Historisch College FNI

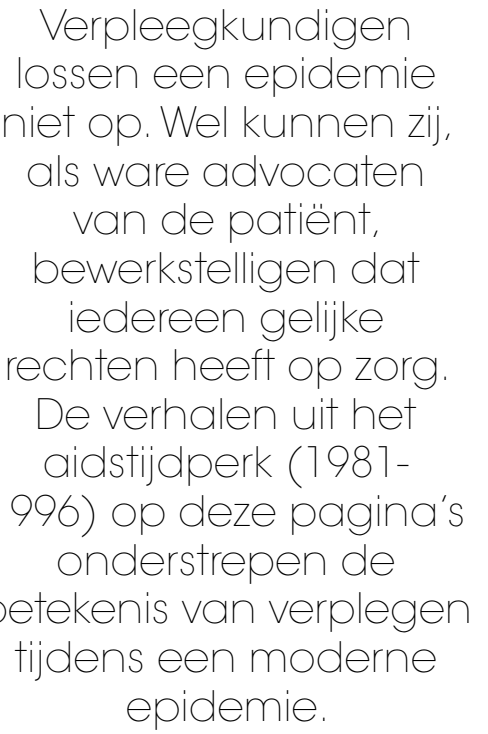

D E COVID-19-CRISIS LAAT ZIEN dat ook anno 2020 de Westerse wereld niet gespaard blijft van epidemieën. Toch voorspelden vooraanstaande microbiologen nog in 1972 dat dergelijke uitbraken in het Westen tot het verleden behoorden dankzij antibiotica en effectieve vaccinatieprogramma's. Epidemieën waren voer voor de historicus, niet meer voor de dokter. ${ }^{1}$

Deze voorspelling bleek al snel onjuist. Binnen een paar jaar stond de medische wereld met de handen in het haar, toen de aidsepidemie zich ontvouwde in de Verenigde Staten. De hardst getroffen groepen, waaronder homoseksuele mannen en harddruggebruikers, werden slachtoffer van victim blaming, een gevaar dat bij elke epidemie op de loer ligt. ${ }^{1}$ Angst voor de ziekte en de grote vooroordelen over de leefstijlen van de getroffen groepen leidden ertoe dat velen niet de zorg ontvingen die ze nodig hadden.

In Nederland keek men gespannen naar hoe de epidemie zich ontwikkelde in de Verenigde Staten. Om een dergelijke situatie te voorkomen, hanteerden Nederlandse beleidsmakers, beïnvloed door een sterke Nederlandse homobeweging, een beleid dat paniek en stigmatisering moest voorkomen. ${ }^{2}$ Dat lukte grotendeels. Niet in de minste plaats dankzij de verpleegkundigen die zich inzetten in de strijd tegen aids en de vooroordelen jegens mensen met de ziekte. Zij zorgden ervoor dat iedere patiënt, ongeacht geaardheid, afkomst, gender of klasse, de zorg zou krijgen waar hij of zij recht op had. Helaas zijn deze verhalen in de loop der jaren naar de achtergrond gedrukt door de verhalen van beleidsmakers en artsen. $\mathrm{Nu}$, meer dan ooit, zijn de verhalen relevant. Ze kunnen dienen ter inspiratie voor het verplegend personeel dat alle zeilen bijzet om de huidige crisis te overwinnen.

\section{Belangenbehartiging}

Jeannette Kok was een van de eerste Nederlandse verpleegkundigen die in aanraking kwam met aids. Als verpleegkundige op de soa-polikliniek van de GGD Amsterdam kreeg zij de opdracht in kaart te brengen hoe de epidemie zich verspreidde. 'De meeste mensen die ik sprak, waren bang en onzeker, omdat ze niet wisten wat het was.' Door haar onderzoek kwam Kok in contact met een groot deel van de vroege aidsgevallen. De eerste aidspatiënten kwamen vrijwel allemaal onder behandeling in het AMC in Amsterdam, waar Kok ook een kantoor op de poli had. Na hun bezoek aan de dokter wipten patiënten steevast bij haar langs. Ze hadden behoefte aan een gesprek met 'een bekend gezicht'. Het ging dan vaak niet over medische informatie, maar over zaken als 'Hoe vertel ik het mijn moeder? En hoe mijn baas?' 'Want aids, dat was taboe. Dat kun je niemand vertellen.'

Samen met een psycholoog organiseerde Kok groepsgesprekken met mensen met aids. Ze creëerden een veilige plek om over dergelijke zaken te praten. Uit deze groep werd de Belangenvereniging voor Mensen met Aids opgericht, later Hiv Vereniging Nederland. Kok moest in het bestuur, tegen haar werd gezegd: 'We willen met de kop in de krant, het moet uit zijn met het taboe. Maar wij gaan 
dood en jij niet, dus jij moet erbij.' Kok wierp zich op als belangenbehartiger voor mensen met aids, iets wat zij bijna 20 jaar zou doen.

Zelf stond ze overigens maar weinig in de schijnwerpers, veel belangriiker vond ze het dat mensen met aids dat deden.

'Mensen met aids kunnen praten vanuit hun eigen ervaringen. Wat het met ze doet als iemand geen koffie uit dezelfde beker durft te drinken of eerst drie handschoenen aantrekt voordat hij je wil aanraken. Dat grijpt veel meer aan dan als ik het zelf had gedaan.' Door te ondersteunen bij voorlichtingen gaf Kok mensen met aids een gezicht. En deed ze er alles aan om de stigma's rondom de ziekte en de patiëntengroep te doen verdwijnen. Behalve voorlichting verleende de vereniging juridische hulp en bood ze ondersteuning rondom bijvoorbeeld de aanvraag van verpleegmiddelen. Jeannette Kok werd hiermee bijna letterlijk advocaat van de patiënt, hoewel zij als verpleegkundige niet meer bij de directe patiëntenzorg betrokken was.

\section{'Ervaringen uit de aidsepidemie dienen nu ter inspiratie'}

\section{Verpleegkundig consulenten}

Met het oog op het stijgende aantal mensen met aids startten in 1985 drie verpleegkundig aidsconsulenten op de polikliniek interne geneeskunde van het AMC. Klaas Hoeksema was een van hen. Hij wilde koste wat het kost een 'Amerikaanse situatie' voorkomen. 'Daar wilden het verpleegkundig personeel en de artsen soms niet eens de kamer op komen. En als ze dat wel deden, dan alleen ingepakt als marsmannetjes. Ik wilde mijn uiterste best doen om het beter leefbaar te maken in Nederland.'

Johan Lambregts, collega van Hoeksema, had geholpen bij het inrichten van de functie aidsconsulent. Een gloednieuwe functie. 'We begonnen gewoon. We leerden in de praktijk en droegen die kennis

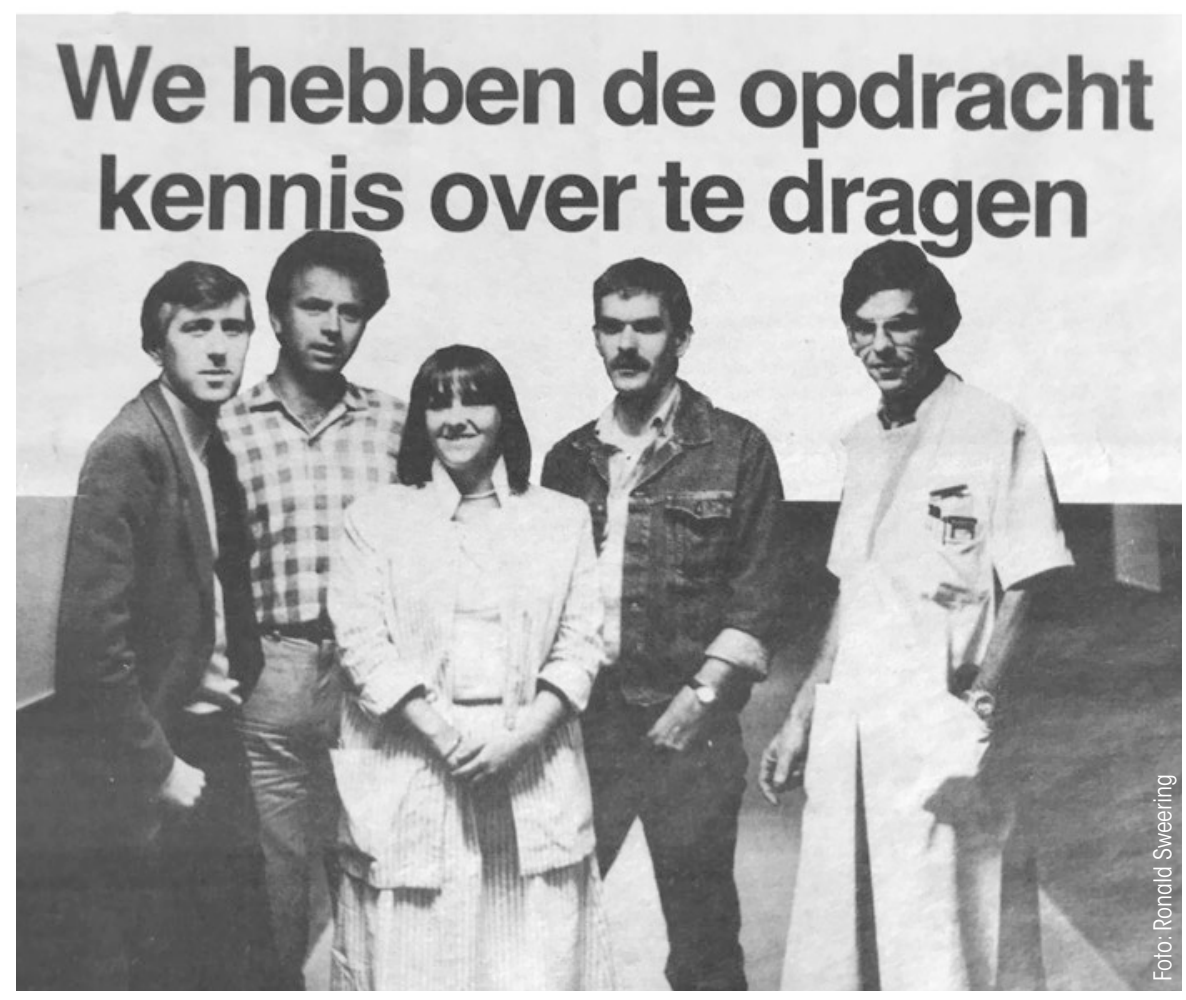

Het eerste aidsteam van het AMC (1985): Sven Danner, Johan Lambregts, Irene Cabri, Klaas Hoeksema en Jan Karel Eeftink Schattenkerk. ${ }^{3}$

weer over aan de verpleegkundigen op de afdelingen.' Het overdragen van die kennis aan collega's was hard nodig, merkte Lambregts. Er heerste veel angst. "Er was angst voor besmetting. Daarnaast betrof het niet de groepen waar verpleegkundigen bij voorbaat bekend mee waren. Homomannen met heel andere leefstijlen, drugsverslaafden. In combinatie met de besmettelijkheid en de dodelijkheid van de ziekte werd het een complex geheel."

Om de angst tegen te gaan, gaven de aidsconsulenten veel voorlichting aan hun collega's. Dat was nodig om goede zorg voor mensen met aids te garanderen. Tijdens de voorlichtingen stuitten de consulenten weleens op vooroordelen tegen de patiëntengroepen. Hoeksema: 'In Limburg was een microbioloog die een heel betoog hield over dat homo's geen mensen waren, maar beesten. Dat ze de ziekten zelf voortzetten en dat het ziekenhuis ze niet moest helpen. Ik pikte dat niet, we stopten de voorlichting en begonnen weer van voor af aan.' Aidsconsulenten gaven niet alleen voorlichting, maar waren ook de spil in de zorg voor mensen met aids. Hoewel er geen effectieve behandeling voor de patiënten was, konden de consulenten veel voor hen betekenen. In hun spreekkamer vingen ze met een kop koffie patiënten op nadat die de arts hadden bezocht. Dan werden alle afspraken 'informeel maar deskundig' nog eens doorgenomen. Lambregts probeerde zo goed als het kon te helpen met de angsten rondom de slechte prognose. 'Je probeerde dicht bij de mensen te blijven en hen te helpen in hun dagelijkse sores. Aids heeft goed laten zien wat de verpleegkundige discipline voor dit soort terminaal zieke patiënten kan betekenen als ze daarvoor de ruimte krijgt.'

\section{Aids in de wijk}

Wijkverpleegkundigen en verzorgenden kregen ook te maken met aids. Jos Eggenkamp zou als aidsverpleegkundige bij het Amsterdams Kruiswerk een drijvende kracht zijn in de zorg voor mensen met aids thuis. 'Er heerste veel hysterie en veel onwetendheid over aids. Er werd van alles gedacht over de besmettelijkheid van aids, dat je het kon krijgen van gebruikte drinkglazen of de welbekende deurknop. Daarnaast waren 
er veel vooroordelen en een zekere 'eigen schuld dikke bult-mentaliteit'. Deze houding was schadelijk, want mensen met aids kregen daardoor niet de zorg die zij nodig hadden. Eggenkamp hield zich daarom vooral bezig met de vraag 'hoe krijg je aids en, vooral ook, hoe krijg je het niet?'

Hij gaf talloze voorlichtingen aan zijn collega's. Aidsverpleegkundige Eggenkamp nodigde daarbij mensen uit die behoorden tot de hardst getroffen groepen: homomannen, maar ook (ex-)verslaafden en prostituees. Groepen waarover veel vooroordelen bestonden. 'Dat was voor wijkverpleegkundigen vaak nieuw, maar daar moesten ze wel wat mee.' Met de wijkverpleegkundigen probeerde hij hun vooroordelen bespreekbaar te maken. 'Het doel van die bijeenkomsten was dat mensen wat milder werden in hun vooroordelen. En ze heel langzaam zover te krijgen, dat ze hun werk gingen doen.

Aids werd een onderdeel van de wijkverpleging, iets waar Eggenkamp nog trots op is. 'Dat heeft te maken met al die voorlichtingen. Ik voelde mij in het begin een soort vertegenwoordiger, maar het werd een wisselwerking. Zo is de trein in beweging gekomen. Het begon met een soort aidssprinter, die daarna een aidsintercity werd. De boel was op de rails gezet. Wijkverpleegkundigen en ziekenverzorgenden gingen opener over seksualiteit praten."

\section{'Verpleegkun- digen namen centrale rol in bij de zorg voor mensen met aids'}

\section{Conclusie}

Verpleegkundigen lossen een epidemie niet op. Wel kunnen zij, als ware advocaten van de patiënt, ervoor zorgen dat iedereen gelijke rechten heeft op zorg. Tijdens een epidemie is dat belangrijk, omdat juist de groepen aan de rand van de samenleving vaak het kwetsbaarst zijn. Dat is ook in de huidige crisis te zien. Verpleegkundigen werken hard op ICU's en speciaal ingerichte COVID-19-afdelingen om zorg te bieden aan de coronapatiënten. Daarnaast zetten verpleegkundigen en verzorgenden zich in binnen andere sectoren, die meer buiten het beeld van het grote publiek vallen. Zoals bijvoorbeeld de gehandicaptenzorg, GGZ of ouderenzorg. Dat is noodzakelijk, omdat cliënten in deze zorgsectoren relatief hard worden getroffen door de maatregelen tegen corona. Te denken valt aan het weren van bezoek en het voor een groot deel wegvallen van de mantelzorg, met alle risico's van dien.

De ervaringen van verpleegkundigen uit de aidsepidemie, zoals die van Jeannette Kok, Johan Lambregts, Klaas Hoeksema en Jos Eggenkamp, kunnen dienen ter inspiratie. $\mathrm{Zij}$ namen een centrale rol in bij de zorg voor mensen met aids. Ze deden wat ze konden om de angst voor aids en de vooroordelen jegens de hardst getroffen groepen onderuit te halen. Zij voorkwamen situaties zoals die zich voordeden in de Verenigde Staten. De epidemie zou uiteindelijk ook niet de vooraf gevreesde Amerikaanse proporties aannemen. We zullen dus (gelukkig) nooit te weten komen of de angst ook was uitgebleven als de epidemie wijder verspreid was geweest. Aan het werk van deze en vele andere verpleegkundigen heeft het in elk geval niet gelegen.

\section{Bronnen}

De auteur putte voor dit artikel uit de volgende bronnen:

- Interview met Johan Lambregts, 4 augustus 2018 te Rotterdam.

- Interview met Jeannette Kok, 15 augustus 2018 te Amsterdam.

- Interview met Jos Eggenkamp, 7 september 2018 te Amersfoort.

- Interview met Klaas Hoeksema, 10 november 2018 te Amsterdam.

De auteur hield de interviews in opdracht van het FNI. Ze staan op film: https://www.fni.nl/pioniers-in-aidsverpleging. Hier zijn kleine delen van het interview terug te zien. Wilt u de complete interviews inzien, bijvoorbeeld voor onderzoek? Dat is mogelijk op aanvraag.E-mail: fni@venvn.nl.

\section{REFERENTIES}

1. Jones, DS. History in a crisis Lessons for COVID-19. The New England Journal of Medicine. 2020;1-2.

2. Mooij, A. Geen Paniek! Aids in Nederland 1982-2004. Bakker, 2004;196-198.

3. Buijze R. AMC start consultschappen voor behandelingen Aids. Actuele zaken. 1985;77,9 (uitgave AZUA). 